Tér és Társadalom 17. évf. 2003/3. 87-101. p.

Tér és Társadalom

XVII. évf. 2003 3: 87-114

GYORS TÉNYKÉP

\title{
VASÚTI KÖZLEKEDÉSÜNK FŐBB PROBLÉMÁI, KÜLÖNÖS TEKINTETTEL A MELLÉKVONALAK FENNTARTHATÓSÁGÁNAK KÉRDÉSEIRE
}

\author{
(Main Problems of Railway Traffic with Special Regard to the \\ Questions of the Sustainability of Branches)
}

KOMLÓS ATTILA

Kulcsszavak:

vasúti közlekedés mellékvonalak Magyarország

A szerzö tanulmányában bemutatja a hazai vasúti közlekedés terén - mind a személyszállitás alakulásában, mind a teherforgalomban - a kilencvenes években lezajlott változásokat, megismerteti az olvasókkal a vasúti infrastruktúra hazánkban tapasztalható minöségi jellemzöit, hiányosságait. Mivel a vasúti közlekedés igen nagy hatást gyakorol a társadalmi-gazdasági folyamatok alakulására, ezért a szerzö foglalkozik a vasúti mellékvonalak kérdéskörêvel is, kitér e vonalak üzemeltetésének, ill. megszüntetésének problematikájára.

\section{Bevezetó}

E tanulmány központi kérdése, hogy a hazai vasúti közlekedésben milyen változások mentek végbe az 1990-es években; áttekinti a személyszállítás alakulását, bemutatja a teherforgalomban lezajlott föbb változásokat. Sarkalatos pont mind a forgalomszervezés, mind a vidéki térségek társadalmi-gazdasági élete szempontjából a vasúti mellékvonalak évtizedek óta fennálló problematikája. A tanulmány foglalkozik a mellékvonalak üzemeltetésének gondjaival, betekintést nyújt a mellékvonalak által érintett térségek vasúti közlekedésének és társadalmi-gazdasági életének főbb összefüggéseibe.

\section{A magyarországi és az EU-országok vasútjai. A fóbb jellemzők összehasonlítása}

\section{A személyszállítás alakulása}

A vasúti személyszállítás hazánkban az 1980-as évek közepétől csökkenő tendenciát mutat. A folyamatnak igen sok, részben a közlekedés szerkezetének változására visszavezethetö, részben a keresletet meghatározó külső összetevője van, közülük a növekvő munkanélküliség, és mindezek hatására az ingázás csökkenése emelhetö ki. A menetdíjak 1951 és 1982 között nem változtak, az azóta eltelt idószakban az 
Komlós Attila : Vasúti közlekedésünk föbb problémái, különös tekintettel a mellékvonalak fenntarthatóságának kérdéseire.

Tér és Társadalom 17. évf. 2003/3. 87-101. p.

emelkedés mértéke meghaladta a konkurens közlekedési eszközök díjnövekedését, és ami még ennél is fontosabb, a fizetöképes kereslet növekedését. Amíg Magyarországon a kilencvenes években csökkent a vasúton utazók száma, addig egyes $E U$ országokban növekedett. A növekedés Ausztriában, Németországban és Olaszországban volt a legnagyobb mértékü. A pozitív tendencia mögött elsösorban környezetvédelmi, racionalizálási intézkedések állnak. A városkörnyéki, agglomerációs vonzáskörzeti közlekedésben is növekedett a vasút abszolút teljesítménye (FehérLovas-Maizl 1997).

Hazánkban 1985-től 1991-ig, hat év leforgása alatt drasztikus mértékben, 44,2 millió fövel csökkent a vasúton utazók száma. E kedvezőtlen folyamat legföbb összetevöje a hivatásforgalom csökkenése volt, a hivatásforgalomban résztvevők száma 6 év alatt 80,2 millióról 50,2 millióra csökkent (1. ábra). A kilencvenes évek első éveiben ezzel szoros összefüggésben áll az utazási távolságok átrendeződése, a helyi forgalomban résztvevök száma jóval nagyobb mértékben csökkent a távolsági forgalom résztvevőinek számához képest. Ez a tendencia egészen 1994-ig állt fenn, ezt követően három éven át a helyi és a távolsági utasok száma közel azonos volt, majd 1997-töl a távolsági forgalomban résztvevők száma lassú növekedésnek indult. A tanulóforgalomban a vasúton utazók száma csekély ingadozást mutat, a kilencvenes évek második felében enyhe emelkedés tapasztalható, azonban ez az emelkedés 1999 után megállt, és lassú csökkenésnek indult.

\section{1. ÁBRA}

A hazai vasúti személyszállítás alakulása 1985 és 2000 között (The Development of the National Railway Passenger Transportation between 1985 and 2000)

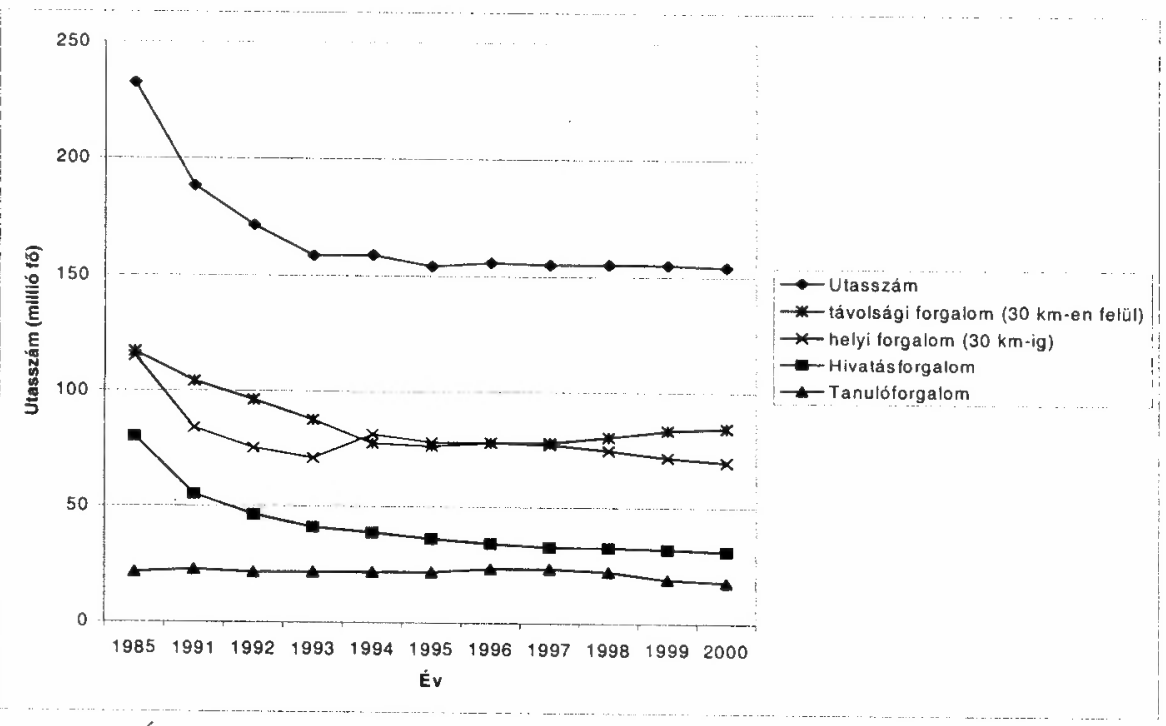

Forrás: MÁV Rt. 
Komlós Attila : Vasúti közlekedésünk föbb problémái, Tér és Társadalom 17. évf. 2003/3. 87-101. p.

\section{Teherszállítás, kombinált árufuvarozás, logisztikai központok}

A vasúton szállított áru mennyisége még az utasszámnál is nagyobb mértékben csökkent az elmúlt évtized elején Magyarországon (2. ábra). A drasztikus visszaesés föbb okai nagyjából a személyszállitással kapcsolatban ismertetettekkel azonosak. A gazdasági recesszióval és a termelési szerkezetváltással a nagy mennyiségú, nagy tömegủ áruk szállitása háttérbe szorult (Ruppert 1998). A termeló és kereskedelmi egységek elaprózódása, számuk gyors növekedése miatt a nagyobb hozzáadott értékủ áruk gépkocsival történő szállítása gyakoribbá vált. Ez a folyamat átalakította a közúti tehergépjármü-forgalom szerkezetét, tovább gyengítve a vasúti áruszállítás pozícióit. A balkáni háború különösen a tranzitforgalmat fogta vissza. A kilencvenes évek elején az EU országainak nagy részében is hasonlóan alakult a forgalom: összességében csökkent a vasutak árufuvarozási teljesítménye, mégpedig igen jelentős mértékben: 432 millió tonnával, azaz 32,3\%-kal (Fehér-Lovas-Maizl 1997). Az áruszállítás teljesítményének csökkenése 1993 előtt volt a legintenzívebb hazánkban, azóta stagnálás, illetve időnként enyhe növekedés figyelhetỏ meg. Azonban a vasúti szállítás részaránya a közúti szállítással összevetve továbbra is zsugorodik (Csiba et al 2000). Ez a tendencia a belföldi, az export, az import és a tranzitforgalomra egyaránt jellemző, sem jelentős növekedés, sem jelentős csökkenés nem ment végbe 1993 óta. A környezetvédelem és a közlekedésbiztonság szempontjából a vasúti áruszállítás részarányának növekedése igen kedvező lenne. Különösen a hazánkon átáramló kamionforgalomból eredö környezetterhelést csökkentené jelentős mértékben a kombinált szállítás alkalmazásának kibővítése.

\section{2. ÁBRA}

A hazai vasúti áruszállitás alakulása 1985 és 2000 között

(The Development of the National Railway Freight Transportation

between 1985 and 2000)

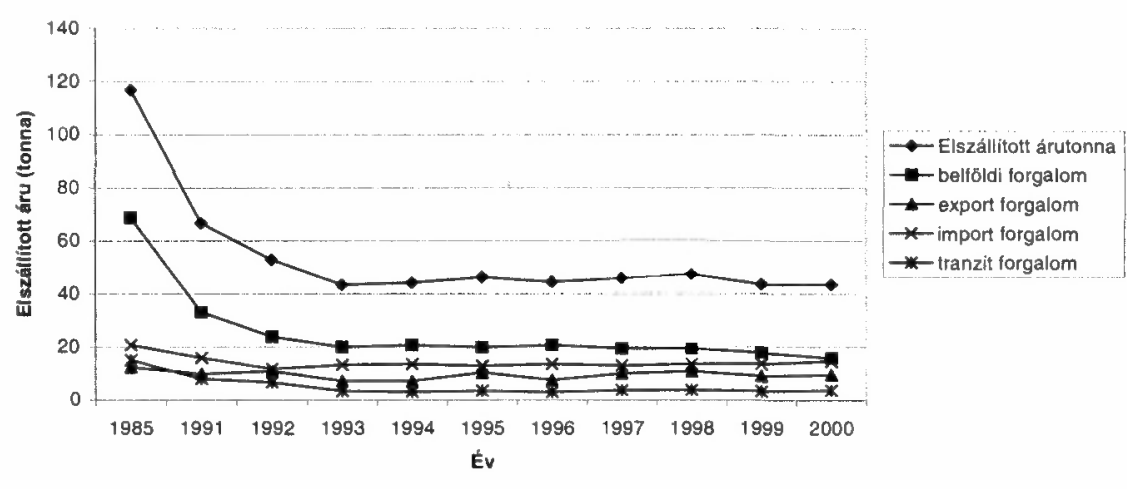

Forrás: MÁV Rt. 
Kísérleti járatok után, a kilencvenes évektől kezdődött meg hazánkban a rendszeres kombinált árufuvarozás (Verbóczky 1998).

A kombinált árufuvarozás fỏbb jellemzöi:

- Gördülö országút (Ro-La): kamionok, nyerges vontatás szerelvényeinek vasúti/közúti/vízi közlekedtetése háztól házig;

- Konténerek, csereszekrények és daruzható félpótkocsik szállítása háztól-házig;

- Értékes kereskedelmi áruk szállításához ideális, mert a konténer, mint csomagoló eszköz védi az árut;

- Nagy távolságú, akár tengerentúli szállítás valósítható meg általa, az áru átrakása nélkül;

- Egységrakományok képzésével integrált logisztikai szállítási lánc alakítható ki;

- A menetrend szerint közlekedö irányvonatok gyors, közvetlen összeköttetést biztosítanak a belföldi és a nemzetközi terminálok között.

A gördülö országút (Ro-La), azaz a kamionok vasúton történő szállítása lehetővé teszi többek között a Délkelet-Európából érkező, a közutat és a környezetet erősen igénybevevő tranzitforgalom egy részének villamos vontatású szerelvényeken történö továbbítását Ausztria, Németország és Olaszország irányába (Varga 1998a). Jelenleg a következő 4 viszonylatban közlekednek Ro-La vonatok: Kiskundorozsma-Wels, Kiskundorozsma-Sezana, Sopron-Wels, Budafok-Háros-Wels. A kombinált fuvarozás azonban még mindig rendkívül alacsony részarányt képvisel a vasúti teherszállításban. Pedig e szállítási mód különösen elönyös az értékes és sérülékeny áruk nagy távolságra történö eljuttatásánál. Részarányának növekedése föként környezetvédelmi szempontból kívánatos (Csiba et al 2000).

A kísérö nélküli forgalom (Huckepack), vagyis konténerek, csereszekrények és félpótkocsik vasúton történő továbbítása 1992-ben indult be Budapest és Bréma/Hamburg között. A menetrend szerint közlekedö irányvonatok, gyors és közvetlen összeköttetést biztosítanak a belföldi és a nemzetközi terminálok között. A viszonylatok elsősorban a nagy tengeri kikötők (Hamburg, Rotterdam, Koper), valamint a Balkán-félsziget törökországi, görögországi és romániai célállomásai felé irányulnak.

A költségcsökkentés és a versenyképesség javítása érdekében a raktározást, az áruelosztást, a csomagolást, a vámolást egy helyen, a logisztikai központokban célszerủ elvégezni. Az európai logisztikai vállalatok tevékenysége igen széles körü, az optimális szállítási útvonal, a legkedvezőbb szállítási mód kiválasztása, a szállítás lebonyolításának megszervezése, a raktározás megoldása stb. egyaránt feladatuk. Azonban a konkrét szállítási feladat lebonyolításán túl komoly gazdasági és politikai befolyásoló tényezöt képviselnek. Ezért az újonnan létesítendő logisztikai központok esetében figyelembe kell venni a gazdasági térszervezö hatásokat is (Meijer-Velden 1996). Magyarország földrajzi fekvése folytán - a tranzit szempontjából - kedvezönek ítélhetök a logisztikai központok létrehozásának feltételei. Az országban összesen 18 kombinált forgalmi terminál müködik, a következő helyeken: Baja-Dunapart, Békéscsaba, Budafok-Hảros (Ro-La), Budapest-József- 
város, Budapest-Kelenföld (üres depo), Budapest-Kikötö, Debrecen, Győr-Kombi, Kiskundorozsma (Ro-La), Miskolc-Gömöri, Nagykanizsa, Pécs, Sopron (Ro-La), Szeged, Székesfehérvár, Szolnok, Szombathely, Záhony.

\section{Hálózat, minöségi jellemzök}

A vasúthálózat sürüsége szempontjából, a fajlagos értékek alapjän, Magyarország igen kedvezö helyzetben van. Az ország egységnyi területéhez viszonyítva a negyedik, a lakosságszámához viszonyítva a harmadik helyet foglalja el Európában. A nagy vonalsürüség azonban korántsem jelenti azt, hogy a hálózat nyújtotta lehetöségek maximálisan ki tudják elégíteni a különféle viszonylatú szállitási igényeket. A pályahálózat centrális szerkezete miatt a vidéki nagyvárosok közötti vasúti közlekedési összeköttetés sok esetben igen nehézkes. Például Pécsről Szegedre csak több átszállással lehet eljutni vasúton. A Duna által kettészelt ország keleti és nyugati része közötti vasúti kapcsolat javítása érdekében célszerủ lenne a meglevő fövonalakra meröleges, transzverzális vonalakat kiépíteni. Számos esetben a mellékvonalaknál is az igen alacsony igénybevétel egyik oka a pálya kedvezötlen vonalvezetésében keresendö, ti. a vonal viszonylata nem a természetes utas- és áruáramlatoknak megfelelö. Az a körülmény is utastaszító, hogy a vasútállomás sok helyuitt távol fekszik az adott településtöl: ezeken a helyeken a közúti közlekedés (autóbusz) vonzereje értelemszerủen nagyobb a vasúténál, kiváltképp, ha a közút és a vasút vonalvezetése párhuzamos. Az alacsony igénybevétel oka természetesen nem kizárólag a vonalvezetésbỏl adódik, legalább ilyen súlya van a müszaki hiányosságoknak, a pálya elavultságának, a kényszerủ sebességkorlátozásoknak, a kedvezőtlen menetrendnek, a munkaképes korú és munkahellyel rendelkezỏ lakosság elvándorlásának.

\begin{tabular}{|c|c|c|c|c|c|c|c|c|c|c|c|c|}
\hline \multicolumn{13}{|c|}{$\begin{array}{l}\text { 1. TÁBLÁZAT } \\
\text { Összefoglaló adatok Magyarország vasúti hálózatáról } \\
\text { (Summarising Data on Hungary's Railway Network) }\end{array}$} \\
\hline \multicolumn{13}{|c|}{ XII. 31-i állapot } \\
\hline & & 1985 & 1991 & 1992 & 1993 & 1994 & 1995 & 1996 & 1997 & 1998 & 1999 & 2000 \\
\hline $\begin{array}{l}\text { Normál nyomtá- } \\
\text { vú }\end{array}$ & $\mathrm{km}$ & 7406 & 7403 & 7392 & 7394 & 7394 & 7513 & 7513 & 7513 & 7513 & 7513 & 7530 \\
\hline $\begin{array}{l}\text { Keskeny nyom- } \\
\text { távú }\end{array}$ & km & 176 & 176 & 176 & 176 & 176 & 218 & 218 & 218 & 218 & 218 & 218 \\
\hline Széles nyomtávú & km & 35 & 35 & 36 & 36 & 36 & 37 & 37 & 37 & 37 & 37 & 37 \\
\hline Összesen & $\mathrm{km}$ & 7617 & 7614 & 7604 & 7606 & 7606 & 7768 & 7768 & 7768 & 7768 & 7768 & 7785 \\
\hline \multicolumn{13}{|l|}{ ebből: } \\
\hline Egyvágányú & km & 6489 & 6439 & 6429 & 6431 & 6421 & 6444 & 6444 & 6476 & 6476 & 6476 & 6493 \\
\hline Többvágányú & $\mathrm{km}$ & 1128 & 1175 & 1175 & 1175 & 1185 & 1324 & 1324 & 1292 & 1292 & 1292 & 1292 \\
\hline Villamosított & $\mathrm{km}$ & 1917 & 2164 & 2184 & 2184 & 2212 & 2401 & 2401 & 2461 & 2504 & 2530 & 2628 \\
\hline
\end{tabular}

Forrás: MÁV Rt. 
A vonalsürüség és a vonalvezetés mellett számos müszaki jellemző is minösíti a hálózatot.

A villamosított vonalak aránya 2000-ben $34 \%$ volt, ez az érték az EU-országok átlaga alatt marad. A kétvágányú vonalakon, az egyvágányúval szemben, növekedhet az áteresztöképesség és a menetrend betarthatósága is könnyebbé válik. A rendkívüli események miatt nem kell leállítani a forgalmat, a másik sínpáron folyhat a közlekedés. Magyarország a kétvágányú pályák tekintetében kifejezetten rossz helyzetben van, az utóbbi évek alatt a két- vagy többvágányú pályák hossza nem növekedett (1. táblázat). A $60 \mathrm{~kg} / \mathrm{fm}$ és ennél nagyobb folyóméter-tömegü sinek hossza mutatja azt, hogy mekkora szakaszon lehet $160 \mathrm{~km} / \mathrm{h}$ (személyszállító vonatok), illetve $120 \mathrm{~km} / \mathrm{h}$ (tehervonatok) sebességgel közlekedni. Magyarországon ez idáig a Budapest-Hegyeshalom vonalon van ilyen felépítmény, de a fontos nemzetközi vonalainkon is rövid időn belül szükség lesz a felépítmények cseréjére. A szerkezetek és a fenntartási technológia fejlettségét a hézag nélküli vágányok hossza jellemzi. Mivel Magyarország Európában élen járt ennek a rendszernek a kifejlesztésében, érthető, hogy ebben a tekintetben előkelő helyet foglalunk el (Nagy 1998).

A közúti és a vasúti hálózat térbeli viszonyáról, metszéspontjairól és potenciális biztonságáról ad információt a müszakilag nem biztosított útátjárók aránya. Magyarországon ez 53 százalékot tesz ki! Nagy gond, hogy az autópályákat leszámítva a forgalmas föközlekedési utak is sokhelyütt szintben keresztezik a vasúti pályát. Kézenfekvö tehát, hogy a szintbeli útátjárók arányát csökkenteni kell. A hidak száma az európai országokban növekedett, ennek oka egyrészt a szintbeli útátjárók kiváltása, másrészt a nagysebességủ pályák építése. A $160 \mathrm{~km} / \mathrm{h}$ sebességre engedélyezett pályák szintbeli keresztezése nem engedélyezett, ez esetben hidat, vagy aluljárót kell építeni. A magyarországi hálózatban a folyami hidak száma rendkívül kevés, a nagyobb folyók továbbra is kemény választóvonalak a hálózatban. A Duna-hidak közül legfontosabb a müszakilag legjobb állapotban levő, budapesti Déli összekötő híd.

A biztositó berendezések kiépítettsége hatással van a közlekedés biztonságára, a teljesítő képességre, de összefüggésben áll a létszám és a költségek alakulásával is. Az önmủködő térközbiztosítás és a központi forgalomirányítás tekintetében Magyarország jóval elmarad az európai átlagtól. A fövonalakon is szép számmal müködnek igen koros, mechanikus biztosító-berendezések, melyek müszaki állapota meglehetősen elavult. A gyakori hibák csökkentik a pontos, hatékony munkavégzés lehetőségét. A sebességkorlátozás mértéke a pályák müszaki állapotáról, és fóként annak rohamos romlásáról árulkodik. Az irányzat több, mint nyugtalanító: 1991-ben a teljes vonalhossz 6,5\%-án, 1996-ban 35,8\%-án, 1998-ban több mint 40\%-án volt érvényben sebességkorlátozás (Csiba et al 2000).

\section{Jármüvek}

A szolgáltatások másik infrastruktúra-feltétele, a vasúti jármüpark, minden elemében és tekintetben kifogásolható, sőt egyes tulajdonságaiban kifejezetten leromlott állapotban van. Ezért a fejlesztési szükségletek óriásiak. A MÁV vontatójármü 
(mozdony) állományában valamennyi vontatási nem jelen van, a forgalomban levő néhány gőzmozdony azonban elsősorban idegenforgalmi célokat szolgál.

A vontatójármüvek közül a fejlett országokban a néhány tagból álló villamos motorvonatok aránya növekszik - amíg régebben csak az elóvárosi forgalomban volt szerepük, addig mára a távolsági és a városok közti forgalomban uralkodóvá váltak. A mozdonyok közül a dízelek száma csökken, a villamos mozdonyok száma növekszik. A villamos mozdonyok közül a nagyteljesítményüek $(3000 \mathrm{~kW})$ aránya nö. $A$ villamos vontatás aránya Európában 80 százalék körül alakul (egyes országokban 90 százalék feletti) Magyarországon viszont 68 százalék. (Nem tévesztendö össze a villamosított vonalak arányával!) A MÁV vontatójármüveinek életkora igen magas, a villamos mozdonyok a hatvanas évek müszaki színvonalán állnak. Ugyan az engedélyezett sebességük 120 , ill. $160 \mathrm{~km} / \mathrm{h}$, de ezt az adottságukat nem képesek kamatoztatni a gyenge pályákon. A dízelmozdonyok többsége Kelet-Európában készült, az alkatrészellátás igen nehézkes, a jármúvek elöregedtek. Ennek ellenére a járművek fenntartására, karbantartására igen kevés pénz jut. A dízelmozdonyok a hatályos környezetvédelmi elöŕrásoknak (levegőszennyezés, zajszint) csak részben felelnek meg (Lovas 1997).

A vasúti személyszállitó jármüvek átlagos életkora igen magas, továbbá kedvezötlen a nemzetközi forgalomra alkalmas kocsik mennyisége. A kilencvenes évek közepétöl a MÁV korszerú, környezetkímélő WC-vel felszerelt légkondicionált személykocsikat vásárolt az EU országaiból (Spanyolországból és Németországból). Ezek az újonnan beszerzett vagonok a nemzetközi forgalomban vesznek részt. A belföldi IC forgalom számára a Dunakeszi Jármújavítóban (részben külföldrơl beszerzett) használt kocsikat alakítottak át. Ezek $140 \mathrm{~km} / \mathrm{h}$ sebességre alkalmasak, de ilyen sebességgel történő közlekedtetésüket a pályák gyengesége általában nem teszi lehetövé. A MÁV a budapesti elővárosi forgalomban 1998-tól korszerü (felújított) személykocsikat is közlekedtet (Varga 1998a; 1998b). Az új beszerzések és a felújítások vontatottsága miatt igen magas az elavult, rossz állapotban levỏ személykocsik száma. A MÁV nem tud olyan szolgáltatást nyújtani, mint amilyent az utazóközönség elváma.

A vasúti teherkocsijaink 82 százaléka 16 évnél idösebb, nagy részük általános célú. Speciális (pl. kamion-, konténer- és áruszállitó, ponyvás, eltolható oldalfalú) kocsik csak az utóbbi években jelentek meg. Mivel ezek a speciális kocsik a fuvaroztatók igényeit jobban kielégítik, folyamatosan növekszik a számuk az EUországokban és hazánkban is (Csiba 1997a).

A veszteséges gazdálkodás és a szabad pénzeszközöket terhelö nagy összegủ adósságszolgálat következtében a pótló jellegü beruházásokat is évek óta csak hitelböl tudja fedezni a MÁV Rt. A vagyonhasznosítási bevételek a vonatkozó kormányhatározat értelmében a fövonalakra, illetve vontatójármüvekre fordítandók, azonban az e címen képezhető forrás messze elmarad az indokolt szükséglettöl. Az állami támogatásokból finanszírozott, döntỏen infrastrukturális beruházások, illetve az EU-forrásokból megvalósuló fejlesztések csak lokális javulást eredményeztek az elmúlt években, a gördülőállomány müszaki állapota a karbantartási, felújítási és 
fejlesztési tevékenység ellenére sem felel meg az elvárt műszaki színvonalnak. A müszakilag indokolt beruházások elmaradása miatt az eszközpark általános müszaki állapota folyamatosan romlik, az ún. „,belső” adósságállomány mintegy 600 Mrd Ft-ra tehetö.

Az eszközök karbantartására, fejlesztésére és felújítására összesen 93,3 Mrd Ft-ot fordított a társaság 2000-ben - 7,2 Mrd Ft-tal többet, mint 1999-ben -, viszont 8,1 Mrd Ft-tal kevesebbet, mint az elöirányzat. A karbantartásra felhasznált összegek az inflációt meghaladó mértékben növekedtek, a felújitási, beruházási lehetőségek azonban reálértéken csökkentek, messze elmaradva az eszközök állapota által indokolt mértéktöl.

A társaság eszközeinek pótlásához, fejlesztéséhez, a fuvareszközök, a személyszállítás alapellátásához szükséges jármüvek felújítását, beszerzését a MÁV Rt. évek óta föként idegen forrásokból, döntően hitelekböl fedezi, miután a veszteséges mủködés és az adósságszolgálat nagyságrendje következtében saját forrású szabad pénzeszköz beruházási célokra nem állt rendelkezésre. Az ún. egyéb források között egyre jelentösebb összeget képviselnek az EU-támogatások (PHARE), továbbá 2000-töl itt szerepelnek a vonatkozó kormányhatározat szerint meghatározott beruházási célokra fordítandó vagyonhasznosítási bevételek is (MÁV Rt. é.n.)

\section{Magyarország vasútvonalainak csoportosítása A mellékvonalak jellemzöi}

A vasúthálózat vonalait a MÁV négy kategóriába sorolja, forgalmi és hálózati jelentőségük alapján:

- nemzetközi törzshálózati vonalak

- hazai törzshálózati vonalak

- egyéb belföldi fóvonalak

- mellékvonalak.

\section{Fövonalak}

A hálózaton belüli forgalmi teljesítmény szempontjából a MÁV Rt. törzshálózatának kiemelkedö a jelentösége, a hazai összes vasúti szállítás 78\%-a ezeken a vonalakon bonyolódik le. Különösen nagy forgalmi teljesítményt mutatnak föl a szintén ebbe a kategóriába tartozó nemzetközi vonalak. A fejlesztéseknél, beruházásoknál érthető módon ezek a vonalak élveznek elsőbbséget a többi kategóriával szemben.

A hazai törzshálózati vonalakon a müszaki paraméterekre vonatkozó előírások a belföldi szállítási igényekhez alkalmazkodnak, így a nemzetközi előírásokhoz mérten szerényebbek. A vonalak állapota helyenként igen leromlott, több szakaszon sebességkorlátozást kellett bevezetni.

Az egyéb belfóldi vonalkategória pályáin az engedélyezett sebesség $80-100 \mathrm{~km} / \mathrm{h}$, müszaki állapotuk elmarad az elözö kategória vonalaitól. 


\section{Mellékvonalak}

Ebbe a kategóriába tartozik a MÁV Rt. teljes vonalhálózatának 35,7\%-a, melynek egy része - mintegy $680 \mathrm{~km}$ - az ún. gyenge forgalmú vonalak közé sorolható. A pályák mủszaki állapota igen leromlott, sok helyen sebességkorlátozásokat kellett bevezetni. A vágányok rossz állapota miatt bizonyos szakaszokon csak kistömegű vontatójármüvek, ill. korlátozottan megrakott vasúti teherkocsik közlekedhetnek. A vonalak így nem tudják kielégíteni a szállítási igényeket, a gazdaságos üzemeltetés sem valósulhat meg. A mủszaki problémák mellett gondot jelent továbbá, hogy a pályák vonalvezetése nem mindenütt felel meg az igényeknek, vagyis a természetes utas- és áruáramlatokkal nem esik egybe. A vonalak müködtetése így sok esetben ráfizetéses, azaz a költségek meghaladják az utas-, ill. teherforgalom révén realizálódó dîjbevételeket. Az üzemeltetési költségek csökkentése érdekében az utóbbi években egyszerüsített forgalmi technológiát vezettek be bizonyos vonalakon. Ez azt jelenti, pl. hogy a vonal mentén levő állomási- és sorompó-berendezéseket a vonatszemélyzet kezeli. Bizonyos vonalakon, ahol a pálya müszaki állapota nem teszi lehetôvé a vasúti forgalom lebonyolítását, beszüntették a forgalmat, a személyközlekedést vonatpótló autóbuszokkal oldják meg (pl. a Pécsvárad-Palotabozsok, a Dombóvár-Mezóhídvég, a Pincehely-Tamási vonalakon.)

A mellékvonalak funkciójuk szerint két csoportot alkotnak. Az egyik csoportba azok a mellékvonalak tartoznak, amelyek ráhordó-elosztó funkciót látnak el, a másikba az összekötő szereppel rendelkezö vonalak tartoznak.

A személy- és áruszállítási szempontból ráhordó-öszekőtő jellegü mellékvonalak/vonalrészek, melyek megtartása a jövöben is indokolt:

Nyugat-Dunántúl

Györ-Veszprém: $79 \mathrm{~km}$, teljes vonal

Harka-Szombathely: $58 \mathrm{~km}$, teljes vonal

Zalaegerszeg-Zalalövö: $25 \mathrm{~km}$, Szlovénia felé nemzetközi vonal

Hajmáskér-Lepsény: $31 \mathrm{~km}$, teljes vonal

Dél-Dunántúl

Somogyszob-Balatonszentgyörgy: $60 \mathrm{~km}$, teljes vonal

Somogyszob-Nagyatád: $9 \mathrm{~km}$, teljes vonal

Godisa-Komló: $19 \mathrm{~km}$, teljes vonal

Szentlörinc-Sellye: $24 \mathrm{~km}$, teljes vonal

Nagyharsány-Villány: 12 km, vonalrész

Pécs-Pécsvárad: $23 \mathrm{~km}$, vonalrész

Villány-Mohács: $24 \mathrm{~km}$, teljes vonal

Észak-Magyarország

Kisterenye-Kál-Kápolna: $55 \mathrm{~km}$, teljes vonal

Eger-Szilvásvárad: $34 \mathrm{~km}$, vonalrész

Miskolc-Diósgyór-Vasgyár: 13 km

Kazincbarcika-Rudabánya: $15 \mathrm{~km}$, teljes vonal

Tállya-Szerencs: $13 \mathrm{~km}$, vonalrész 
Észak-Alföld

Kunhegyes-Kisújszállás: 21 km, vonalrész

Debrecen-Tiszalök: $68 \mathrm{~km}$, teljes vonal

Görögszállás-Tiszalök: $18 \mathrm{~km}$, vonalrész

Kunszentmiklós-Tass-Solt: $30 \mathrm{~km}$, vonalrész

Püspökladány-Szeghalom: $47 \mathrm{~km}$, vonalrész

Dél-Alföld

Szeged-rendezö-Röszke: $13 \mathrm{~km}$, teljes vonal

Kiskörös-Kalocsa: 30 km, teljes vonal

A többi mellékvonal (gyengeforgalmú vasútvonal) szinte kivétel nélkül ráfizetéssel, csak gazdaságtalanul üzemeltethetö, függetlenül attól, hogy milyen költségcsökkentő intézkedéseket vezettek be (egyszerüsített forgalmi technológia). Ezeknek a vonalaknak a jövőjéről mielőbb szükséges dönteni, meg kell vizsgálni, hogy az optimális mủködés biztosítható-e a jövőben. Amennyiben nem, úgy az adott vonal felszámolása után a közúti közlekedés fejlesztésére kell helyezni a hangsúlyt, különösen azokon a területeken, ahol a gyengeforgalmú vasúti mellékvonal és a közút vonalvezetése párhuzamos. A döntések meghozásakor célszerü a külföldi példákat megvizsgálni, hiszen pl. Nyugat-Európa országaiban is felmerültek hasonló problémák. A rendelkezésre álló tapasztalatokból sok olyan motívum leszürhetö, amely a magyarországi mellékvonalak esetében is alkalmazható lehet: regionális közlekedési szövetségek, különböző szolgáltatók (busz, vasút) közötti kooperáció megvalósítása, ésszerüsítés stb.

A mellékvonalak tárgyalásakor feltétlen meg kell említeni a keskeny nyomközủ vasútvonalakat is. Ezen vonalak egy része a MÁV, más része különböző gazdasági társaságok kezelésében áll. A kisvasutak többsége eredetileg gazdasági célból épült, napjainkban viszont a meglevö vonalak elsősorban idegenforgalmi célokat szolgálnak (Thorday 1997).

\section{Valóban csak veszteséget termelnek a mellékvonalak?}

\section{Területi különbségek}

Az első részben már említésre került, hogy a rendszerváltozást követő időszakban mind a személy-, mind a teherszállítás csökkenő tendenciát mutat. A változás azonban országrészenként eltérő módon jelentkezik. A személyközlekedés a gazdaságilag fejlettebb térségekben növekedett, míg az elmaradott, leszakadó térségekben visszaesett.

Az ország térségei között fennálló elmaradottságbeli különbségek az elmúlt évtizedekben nem csökkentek. Az elmaradottság, az infrastruktúra alacsony kiépítettsége, az adott térség elérhetőségének korlátai a fejlődés akadályát jelenthetik. Ahhoz, hogy az egyes országrészek közötti különbségek csökkenjenek, a fejlődés egyenletes legyen, tudatos terület- és településfejlesztési politikára van szükség. A területfejlesztési politika egyik jellegzetessége az ország különbözö térségeinek differen- 
ciált kezelése. Ennek oka az, hogy a rendszerváltozás utáni években az egyes területek a bekövetkezett változásokra eltérỏen reagáltak, ennélfogva térségenként különböző stratégiákat kell kidolgozni, egységes, országos stratégiát nem lehet alkalmazni.

\section{A területfejlesztési politika és a vasúti közlekedés}

A közlekedést szabályozó törvények csak a távolsági és a helyi közlekedést érintik, a regionális szintről nem rendelkeznek. A közlekedésfejlesztés szempontjából jelenleg nincs pontosítva az országos (állami) és a helyi (önkormányzati) közforgalmú vasút közötti átmenetnek megfelelö - és a mellékvonalak szempontjából alapmegoldásnak tekinthetö - ún. regionális közforgalmú vasút definíciója. Márpedig az alapellátás, vagyis az alapfokú ellátást biztosító intézmények múködését és használatát elősegítỏ közlekedési szolgáltatás meghatározásában ez igen fontos lenne. Az alapellátásnak lehetỏvé kell tennie, hogy:

- az ország bármely állomásáról Budapestre való eljutás és visszautazás egy naptári napon belül megvalósítható legyen;

- az ország bármely állomásáról egy naptári napon belül az ország bármely másik állomására megoldható legyen az eljutás;

- a vasúti csomópontok vonzáskörzetében a személyvonatok közlekedése a múszakrendekhez és az iskolakezdéshez igazodjon.

A területfejlesztés a térség közlekedésének fejlődését is elősegítheti, így a vasúti közlekedést is. Az egyes régiók közötti összeköttetések megteremtésében a vasútnak a jövöben is fontos szerepe lehet. Az újonnan létesülő ipari parkok esetében is célszerú lenne a vasúti kapcsolatok kiépítését is szorgalmazni - a már meglévők között is számos olyan van, amelyik nem rendelkezik vasúti kapcsolattal.

\section{Gazdaságtalan mellékvonalak - elmaradott térségek}

A vasúti mellékvonalakat és az általuk érintett területek gazdasági és társadalmi életét érzékenyen érintette az 1968. évi Közlekedéspolitikai koncepció, melynek távlati célja az ,arányos, nagy hatékonyságú, komplex és korszerủ közlekedési rendszer" kialakítása volt. A koncepció közel 2000 km vasútvonal és több száz vasútállomás megszüntetését irányozta elő. Hogy végül mely vonalakat szüntették meg, és melyek maradhattak, sok esetben a helyi erőviszonyok (politikai szempont) döntötték el. Elöfordult, hogy a menetrendet úgy állították össze, hogy sem iskolába, sem munkába, sem piacra járásra nem volt megfelelỏ. A vasútmegszüntetések tovagyưrüzö hatásait (települések fejlödése, munkaerömozgás stb.) nem vették figyelembe a kisforgalmú mellékvonalak megszüntetésekor. 1968 és 1982 között $634 \mathrm{~km}$ normál, $360 \mathrm{~km}$ keskeny nyomtávú és 677 km gazdasági vasútvonalat számoltak fel Magyarországon (Erdösi 1991).

A gazdaságtalan vasútvonalak megszüntetése és az általuk érintett területek leromlása között kimutatható összefüggés van: a lezárt vasútvonalak mentén erősödött a korábban tapasztalt elmaradottság. A vonalak gazdaságos üzemeltetése azon- 
ban igen nehéz feladat az ilyen térségekben, viszont megfelelő utasszámmal, mellékvonali forgalomra alkalmas jármüvek üzembeállításával, egyszerüsített állomási szolgálat bevezetésével mégis olcsóbb közlekedést biztosíthat a vasút a közúti közlekedésnél. A személyszállítás esetében elképzelhető megoldás lenne, hogy a MÁV az önkormányzatok, vagy gazdasági társaságok bevonásával egy-egy felhagyott vonal mellett autóbuszokkal bonyolíthatná le a forgalmat. E ponton fölvetődhet, hogy a különböző közlekedési módok közül a vasút környezetterhelése fajlagosan jóval kisebb a közúti közlekedésnél. Viszont abban az esetben, amikor kimutathatóan alacsony igénybevétel mellett közlekednek a szerelvények, a fajlagos környezeti terhelés már jóval meghaladja a kisbuszos közlekedés esetében jelentkező terhelés mértékét.

Az egyes térségek terület- és közlekedésfejlesztését eredményezhetné, ha a kisforgalmú mellékvonalakat az önkormányzatok és a vállalkozók bevonásával üzemeltetnék. Ezen vonalak fenntartásához, fejlesztéséhez ugyanis helyi érdekek füzödnek. A veszteséges vasútvonalak üzemeltetésére korábban felmerült az az elképzelés, hogy önálló regionális vasúttársaságokat hozzanak létre, melyek müködtetését teljes egészében a helyi önkormányzatok és vállalkozások végeznék. Azonban, mivel ezen vonalak szinte kivétel nélkül olyan területeken találhatók, ahol az önkormányzatok anyagi lehetöségei amúgy is behatároltak, rövid idö elteltével felhagytak az elképzelés megvalósításával.

A kormány 2258/1999 (X.14.) Korm. határozata összesen 1000 kilométernyi vonalszakaszt sorol a leggazdaságtalanabb vasútvonalak közé, ezeken a személyszállítási teljesítmény mindössze $1 \%$-ot, az árufuvarozás pedig 0,3\%-ot tesz ki. A MÁV Rt. ezeket a vonalakat a következő kategóriákba sorolta:

- megszüntethetö vonalak (a pálya a forgalomra alkalmatlan, évek óta közútra terelődött a szállítás, a vasúti szállítási igény megszủnt $-159 \mathrm{~km}$ );

- átminősíthető vonalak (azok a vonalak, amelyek iparvágánnyá minősíthetők, mủködésuik nagymértékben függ az iparvágány-használók távlati igényeitől $139 \mathrm{~km})$;

- helyi Volán, illetve vállalkozók részére felajánlható vonalak (ahol az utasforgalom autóbuszra terelése gazdaságosabb lenne, ez összesen $151 \mathrm{~km}$ );

- keskeny nyomközủ vonalak (a vonalak üzemeltetésüket, jármüparkjukat és üzemi épületeiket tekintve elkülönülnek a nagyvasúttól, az üzemeltetés felajánlható önkormányzatoknak, vállalkozásoknak - 214 km);

- regionális üzemelésre kiajánlható vonalak (a hálózaton belül jól elkülöníthető rendszert alkotnak, az adott régiók érdekeit szolgálják - 543 km) (Valet 2001).

A fentiekböl látható, hogy rendkívül köruiltekintően kell eljárni minden esetben, ha a közlekedési szolgáltatások visszafejlesztéséröl döntünk. Lehetséges, hogy az érintett terület lakossága számára a tömegközlekedés - ezen belül pedig a vasút jelenti a legfontosabb kapcsolatot a magasabb hierarchiaszinten levő településekkel és az azokon igénybe vehetö szolgáltatásokkal, a lakosság személygépkocsiellátottságának alacsony volta miatt. A közlekedési kapcsolatok intenzitásának csökkenésével növekedhet a területen a munkanélküliség, tovább romolhat a lakos- 
ság életszínvonala, melynek egyenes következménye az aktív korúak elvándorlása. Nem a megszüntetés jelentheti az egyetlen megoldást, hanem a szolgáltatások oly módon történő átalakítása, hogy azok a tényleges igényeket kielégítsék, és közben a lehetőségekhez mérten a legkisebb veszteséget termeljék a müködtetỏ számára.

\section{Németországi tapasztalatok}

A regionalizálásra vonatkozó EU-irányelveket és határozatokat Németország a „Regionalizálási Törvényben” vette át és konkretizálta a vasúti kistávolságú személyközlekedésre, valamint az egyéb közhasznú kistávolságú személyközlekedésre vonatkozóan. A regionalizálás következtében a vasúti kistávolságú személyközlekedés a közigazgatás beszükülö ügykezelési kereteitől megszabadulva, rugalmasan, megfeleló hatáskörrel rendelkező versenytársként tud cselekedni. Felismerték azt, hogy az utasok elvárásaihoz igazodó kínálat egyre több forgalmat tud átvonzani a közútról a vasútra. A kistávolságú forgalom még vonzóbbá tétele érdekében a következő lépéseket kell megtenni: javított szerviz biztosítása, nagyobb komfort és tisztaság, müszaki fejlődés forszírozása, a vitathatatlan ökológiai rendszerelönyök továbbfejlesztése.

Az egyes tartományokon belül regionális célszövetségek és egyesülések veszik át a közúti és vasúti kistávolságú személyközlekedés irányítását. A megalakuló célszövetségek/egyesülések egymással való kapcsolódása természetesen elengedhetetlen egyrészt azért, hogy az utas a "határokon átmenően” is tudja használni a vonatot, másrészt a gazdaságos üzemeltetés is ezt kívánja meg. Az utasoknak lehetöleg átszállásmentes összeköttetéseket, optimális járatcsatlakozásokat kell biztosítani.

A személyközlekedés hatékonysága az autóbusz és vasúti közlekedés optimálisan összehangolt teljesítménykínálatával tovább fokozható. Minden közlekedési eszköznek megvan a maga tipikus rendszerelönye az utasforgalom volumenétöl, az elérhetőségtỏl, az utazási távolságtól vagy az utazási időpontoktól függően. A cél a régió összes közlekedési eszköz fajtájának kooperációja, és az együttes kizárólagos orientáció a közös ügyfélhasznokra (egy menetrend - egy menetjegy - egy ár). Az integrált ütemes menetrend lehetôvé teszi azt, hogy a régió minden kiszolgált helyét kötött, könnyen megjegyezhetö ütemben egymással összekapcsolják. Az egyes vonalakat a kapcsolódási pontokon (csillagállomások) az egész hálózatra kiterjedő, ütemes kínálatrendszerbe fogják össze. A regionális ráhordó buszjáratok - különösen a ritkán benépesült térségekben - akkor csatlakoznak a vonatokhoz több irányban, ha a hálózati menetrendjük koordinált a csillagállomásokkal. A rendszer további finomításának részei a hívható gyüjtötaxik, vonaljárati taxik és polgárbuszok, amelyek a ritkán lakott, kis közlekedési keresletủ területeken nyújtanak gazdaságos közlekedési kínálatot (Rixer 1998). 


\section{Összegzés}

Az infrastruktúra a kiépítettségétől, mủszaki állapotától, teljesítóképességétől függően segítheti, de leromlása, megszüntetése gátolhatja is a gazdaság hatékony mủködését. A vasúti közlekedés a kezdeti időszaktól - a 19. század közepétöl igen nagy hatást gyakorol a társadalmi-gazdasági folyamatok alakulására Magyarországon.

A rendelkezésre álló információk, adatok alapján arra következtethetünk, hogy a magyarországi vasúti közlekedés teljesítöképessége, igényekhez való alkalmazkodása bőven hagy kívánnivalót maga után, mind a teher-, mind a személyközlekedés terén.

Magyarország gazdaságának fejlödése érdekében, illetve azért, hogy hazánk minél több szállal és minél intenzívebben kapcsolódhasson be a nemzetközi munkamegosztásba, szükség van az infrastruktúra folyamatos, igényekhez igazodó fejlesztésére. A fejlesztések egyik legnagyobb akadályát, ahogy a gazdaság szinte minden területén, úgy itt is a finanszírozás nehézségei, az anyagi források szükössége jelenti. Nem szabad azonban megfeledkezni arról, hogy a rendelkezésre álló eróforrásokkal való ésszerü gazdálkodás nagymértékben hozzájárul a hatékony múködéshez. A különbözö közlekedési szolgáltatók, a vasúti, közúti, vízi és légi fuvarozók közti, országos szinten megvalósuló kooperáció - a közlekedési eszközök rendszerelőnyeit figyelembe véve, az igényekhez igazodva - a pénzügyi szempontból is kedvezö müködést szolgálhatja, ezen felül gazdaságélénkító hatást is indukálhat. A dinamikusan fejlődő, megerősödő gazdasági háttér pedig biztosíthatja a további infrastruktúra-fejlesztés anyagi bázisát.

\section{Irodalom}

Csiba J. (1997a) Jármüvek, a szolgáltatás mozgó elemei. - Európai Tükör Mühelytanulmányok. 9. 101-106. o.

Csiba J. (1997b) Minöségpolitika. - Európai Tükör Mïhelytanulmányok. 9. 127-129. o.

Csiba J.-Lovas J.-Németh Á.-Neuschl Gy.-Maizl E.-Urbán L.-Preislerné dr. Csehalmi D.-Küller L. (2000) A vasút közelmúltja, jelenlegi helyzete és perspektívái. - Nagy E.-Galambos Zs. (szerk.) Infrastruktúra - legújabb tapasztalatok, következtetések, teendök (I.) Mühelytanulmányok. 70. Miniszterelnöki Hivatal Stratégiai Munkacsoport, Budapest. 7-45 o.

Erdősi F. (1991) A közlekedési hálózat kialakulása és részleges megszüntetése. Kommunikáció és térszerkezet. MTA FKI. Budapest. 104-145. o.

Fehér L.-Lovas J.-Maizl E. (1997) A szállítási igények alakulása a vasútnái. - Európai Tükör Mühelytanulmányok. 9.87-93, o.

Horváth Gy. (1998) Magyarország regionális politikája és a csatlakozás teendói. - Ezredforduló. 2. 21-23. o.

Lovas J. (1997) Környezetvédelem és biztonság. - Európai Tükör Mühelytanulmányok. 9. 130-131. o.

Meijer, M.-Ten Velden, H. (1996) Spatial aspects of logistics activity. - EUREG. 3. 49-54. o.

Nagy J. (1998) Hézagnélküli vasúti felépítmény alkalmazásának fekvésbiztonsági alapjai, fejlesztésének lehetöségei. - Közlekedéstudományi Szenle. 1. 29-36. o.; 4. 129-135. o.; 10. 365-377. o.

Polgár L. (1997) Tulajdonformák és a változás tendenciája Magyarországon. - Európai Tiukör Mühelytanulmányok. 9. 109-116. o.

Ritoók P. (1997) A hálózat és a létesítmények, mint a szolgál tatás helyhez kőtơtt alapelemei. - Európai Tükör Mühelytanulmányok. 9. 94-100. o.

Rixer A. (1998) A vasúti regionalizálás európai gyakorlata és hazai irányai. - Közlekedéstudományi Szemle. 9. 341-351. o. 
Komlós Attila : Vasúti közlekedésünk föbb problémái,

Ruppert L. (1998) A magyar közlekedés helyzete, szerepe az Európai Unióhoz történỏ csatlakozásban. Közlekedéstudományi Szemle. 10.383-386. o.

Thorday Z. (1997) Hegyen-völgyön kisvasúton. Magyarhon, Tatabánya.

Valet L. (2001) A vasútreform a terủletfejlesztési és környezetvédelmi szempontok tủkrében. - Hahn Cs. (szerk.) A közlekedéspolitika az ország területfejlesztésében. Hazai Térségfejlesztö Rt., Budapest. 89-96. o.

Varga K. (1998a) A magyar közlekedési vállalatok új és felújított sínjármüvei. - Közlekedéstudományi Szemle. 4. 143-151. o.

Varga K. (1998b) A magyar jármúipar az Industria `98-Transexpo szakkiállításon. - Közlekedéstudományi Szemle. 10. 358-364. o.

Verbóczky J. (1998) A kombinált árufuvarozás helyzete Magyarországon. - Közlekedéstudományi Szemle. 2. 71-78. o.

http://www. mav.hu 